\title{
Ocean Science \& Technology research across the countries: A global scenario
}

\author{
PRABIR G. DASTIDAR \\ Integrated Coastal and Marine Area Management (ICMAM), Department of Ocean Development, \\ Chennai (India) \\ In this paper attempt has been made to unfold the intellectual base in ocean science and \\ technology. The articles appeared in Science Citation Index (SCI) under Oceanography in the year \\ 2000 were analyzed to decipher the scientist to scientist , organization to organization and country \\ to country network structures. The causal linkages between the knowledge productivity function \\ and the socio-economic imperatives of knowledge production units were studied.
}

\section{Introduction}

Ocean has always been an inseparable component of human existence. From the origin of life right up to its continuous sustenance, ocean has always played a strong role in shaping the destiny of the mother earth by exerting a profound influence on it's resources and environment. Most of the earth surface, as large as $70 \%$, is covered by ocean. In spite of its ubiquitous presence it has always remained a mystery to the mankind, waiting to be understood and fully explored. It is estimated that more than half the world's population live within $60 \mathrm{~km}$ of the shoreline, and this could rise to three-quarters by the year 2020 (UNCED, 1992).

Rapid growth of population, utilization of resources to meet the requirement of the changing lifestyle which demands rapid utilization of limited resources of lands, the attention is turning towards a comparatively less explored reservoir of resources - The Ocean. In this work attempts have been made to understand the intellectual structure of Ocean Science and Technology by unfolding the country to country, institute to institute and at unit level scientist to scientist network structure, and its relational linkages with socio-economic imperatives of the countries.

Received August 25, 2003

Address for correspondence:

PRABIR G. DASTIDAR

Integrated Coastal and Marine Area Management (ICMAM), Department of Ocean Development,

NIOT Campus, Velachery-Tambaram Main Road, Chennai - 601302, India

E-mail: prabirgd11@rediffmail.com

$0138-9130 / 2004 /$ US $\$ 20.00$

Copyright (C) 2004 Akadémiai Kiadó, Budapest

All rights reserved 


\section{Methodology}

While there may be several indicators to study science \& technology dynamics, research publications in peer-reviewed scientific journals are widely regarded as one of the most important indicators. The journals that make its way to Science Citation Index (SCI) database of Institute of Scientific Information, Philadelphia pass through a standard and uniform quality check making the data reliable for comparison and structural analysis.

4008 articles from 35 journals for the year 2000, under oceanography category, were downloaded from SCI (CD-ROM version). Oceanography category also includes journal of Ocean Engineering specialty. Articles covered in these journals, commonly referred to as international 'mainstream research', provide a representative picture of the structure of knowledge in the subject specialty. Author names, organization names and country names were isolated separately and rank ordered (PERSSON, 2002). The most productive scientists were chosen to form co-occurrence matrices to which a multidimensional scaling algorithm (a systat sub-routine) was applied to produce the network maps. In case of countries and organizations also the same methodology was adopted. The size of the circles is proportional to the size of the attributes, and the lines between the attributes indicate presence of collaboration links while the width reveals the size of the frequency.

\section{Results and discussion}

Oceanography is a multifaceted discipline. Ocean is a single mass of water body encompassing the entire earth. From time immemorial ocean has been used for joint ventures like trade and commerce, science is no exception. Spirit of collaboration is natural in this discipline. In addition to its multidiciplinarity and its reflexivity, the scientific enterprise is organized at various levels of aggregation (LEYDESDORFF, 2001) and under certain conditions it is possible at some of these levels to convert resources and results into the one another (LATOUR \& WOOLGAR,1979). Three kind of linkages were explored; these maps are the representation of knowledge networking at individual level, organizational level culminating into country level.

The communication pattern between the production units reflects the knowledge structure of the subject specialty. The social and economic conditions are important determinants for the research activity structure of the countries. The scientific activities of the countries are the reflection of their intellectual and social imperatives. 
Some international events in the field may be marked as the booster for the rising level of activities in Ocean sector across the world, apart from the fact that some countries enjoy a rich maritime history, and naturally they become a strong activity center. Challenger expedition initiated by Royal Society of London in 1872 to study the 'condition of deep sea throughout all of the great basins' considered to be the first organized scientific expeditions in the world. The United Nations Convention of the Law of the Sea (UNCLOS), adopted in the year 1982, played an important role in establishing a legal regime of the Oceans - coastal states and islands, led to the spurt of activities in Ocean sector in the world. 1998 was celebrated as the International Year of the Ocean' signifying its growing importance and imperative need to improve the understanding of the Ocean and its various inter-related processes. Legal Continental Shelf (LCS) program, under UNCLOS, is involved with the measuring the extent of continental shelf of the nations for outlining the sovereign boundaries of the nations. The geopolitical importance of the issues may be an important motivating factor for increasing number of international programs with multinational commitments.

Oceanic processes and climate dynamics are intimately inter wined. Understanding the dynamics of climate change and its predictability could be of enormous economic and societal importance - knowing a season or more ahead, how much rainfall is likely to occur, can influence the decision on which crop to plant, such knowledge can affect farming, insurance, energy distribution and myriad other activities over large regions. A better understanding of ocean circulation and the feedback mechanism between the ocean and atmosphere is crucial to improving our ability to forecast climate. The World Ocean Circulation Experiment (WOCE), an unique program with participation of around 30 nations under the leadership of USA generated high quality data led to new insights into how the ocean operates as well as evidence for long term variations and changes. Main participating institutes like National Aeronautics and Space Administration (NASA) \& National Oceanic and Atmospheric Administration (NOAA) of US occupying leading positions in the list of most productive institutes in Ocean Science \& Technology. The networks maps (Figures 2 and 3 ) are showing large clusters working on oceanic processes and climate change. In fact, the leading position of USA corroborates the fact that it has become an active center of origin and coordinating point of many important international programs.

In modern day research economic conditions play a major role. Oceanography is no exception. It is a point to note that all the top five countries in terms of productivity are members of the elite G-5 group (Table 2). While all the top 25 countries are members of the Intergovernmental Oceanographic Commission (IOC) of United Nations, an active forum dealing with ocean and ocean related issues, showing their interest and commitments in Ocean sector. 


\section{Country to country network}

Cutting edge science in many fields increasingly involves a broad range of knowledge perspectives and techniques that extent beyond a given discipline or institution. In oceanography research questions are mostly multidisciplinary covering wide range of environmental regimes cutting across geographical boundaries of the countries. Collaboration between the countries widens the scope to address the issues.

The countries were rank ordered according to the scientific output. Top 25 countries were chosen to produce the network structure (Table 2). USA is found to be leading the list with around $50 \%$ of world share in knowledge production followed by UK, Germany, France, Japan and Canada. The countries at the core of the cluster are members of elite G-5 group, indicating their positional advantage in the network, Broadly, in the network map the countries are arranged in 3 concentric circles, the center is occupied by the G-5 countries followed by Australia, Canada, Russia, Netherlands etc., while the outer ring is dominated mostly by developing countries like India, Brazil, etc. ( Figure 1).

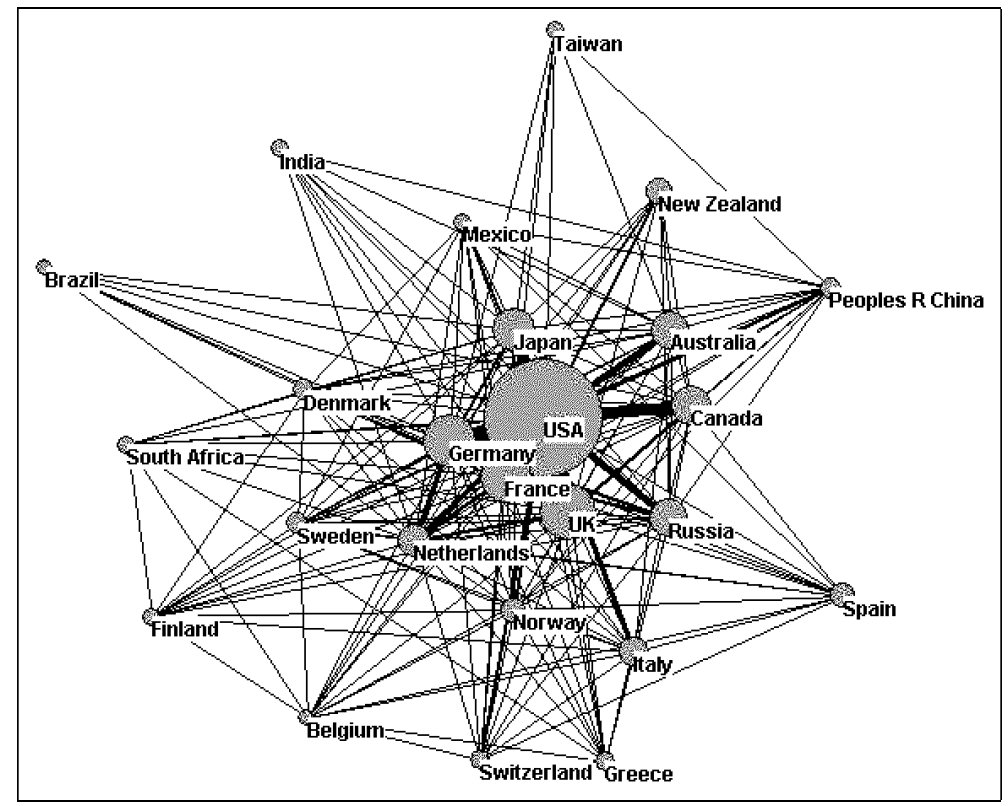

Figure 1. Country collaboration map (Co-authorship) 
Network Analysis. Apart from giving visibility to the scientists, collaboration provides flexibility to the countries to address multidisciplinary and multispatial issues that oceanography demands. Countries with more cooperation links, as in the case of the USA, are already acknowledged as the site of advanced research in the field and many of the links are forged by less advanced countries seeking to tap their expertise. Besides, the collaborating countries are better placed to address research questions as they can enjoy the benefit of having the power of collective wisdom and less dependent on any particular country, hence they are supposed to be more influential in the field.

The data on cooperation links were tabulated in the form of valued adjacency matrix where

$$
\mathrm{C}=\left|\mathrm{C}_{\mathrm{ij}}\right| .
$$

Where Cij, denotes the number of cooperation links between country i and county $\mathrm{j}$. Obviously

$$
\mathrm{C}_{\mathrm{ii}}=0 .
$$

Scientific cooperation between the countries is a function of scientific size of the countries, while the pattern is not. The pattern of cooperation must be viewed without the confounding effects due to size. For controlling the effect of the size, a special index - Salton Index - was computed by using the following formulae (NAGPAUL, 2001):

$$
\text { Salton Index }=\frac{\mathrm{C}_{\mathrm{ij}}}{\sqrt{\sum_{\mathrm{i} j \mathrm{j}}}} .
$$

The entries in the matrix indicate the strength of cooperation links between pairs of countries. Since the links are bi-directional, the matrix is symmetric. 202 cooperation links $(67.33 \%)$ are observed out of 300 [n(n-1)/2] expected links. Certain countries have strong links with many other countries; their network of cooperation is quite extensive. In other words, they occupy a central position in the international network of science. In this study Bonacich Power Centrality is used to indicate the position of the country in the network. It uses iterative weighting to assign higher scores to actors who have stronger ties to more central actors. 
P. G. DASTIDAR: Ocean Science \& Technology

Table 1. Network Centrality of top 25 countries

\begin{tabular}{|c|c|c|}
\hline Rank & Country & Bonacich Power \\
\hline 1 & USA & 2.390 \\
\hline 2 & Germany & 1.480 \\
\hline 3 & UK & 1.470 \\
\hline 4 & France & 1.320 \\
\hline 5 & Canada & 0.920 \\
\hline 6 & Japan & 0.910 \\
\hline 7 & Russia & 0.880 \\
\hline 8 & Netherlands & 0.860 \\
\hline 9 & Australia & 0.820 \\
\hline 10 & Italy & 0.770 \\
\hline 11 & Norway & 0.750 \\
\hline 12 & Sweden & 0.750 \\
\hline 13 & Denmark & 0.640 \\
\hline 14 & Finland & 0.560 \\
\hline 15 & Switzerland & 0.550 \\
\hline 16 & "Greece & 0.530 \\
\hline 17 & Belgium & 0.520 \\
\hline 18 & Peoples R China & 0.520 \\
\hline 19 & Spain & 0.510 \\
\hline 20 & South Africa & 0.430 \\
\hline 21 & New Zealand & 0.410 \\
\hline 22 & Mexico & 0.400 \\
\hline 23 & India & 0.290 \\
\hline 24 & Taiwan & 0.260 \\
\hline 25 & Brazil & 0.240 \\
\hline
\end{tabular}

Not surprisingly, the centrality list places six G-7 countries on top, Russia being the other country occupying the seventh place.

Country clusters and Institute clusters. The organizations and the countries leading the rank order, are actively pursuing many international projects. Uninterrupted time series data is an essential prerequisite to understand climate change. The Climate \& Global change program of National Oceanic and Atmospheric Administration (NOAA) is involved with producing scientifically controlled oceanographic databases. NOAAAVHRR satellite is a popular satellite collecting ocean data from around the world. Countries having deployed satellites, floating sensors etc. for ocean data collection are 
there in the top layer of the list. USA, UK, Japan, France, Canada, Australia and India are working together for an ambitious project of deploying 3000 profiling floats distributed all over the global ocean for continuous collection of data on oceanic parameters across the globe.

S. Levitus leading the list as most referred scientist in the field, is responsible for producing world ocean atlas for different parameters. These atlases are produced under NOAA climate and Global Change program. Levitus data is popular among scientists, as the data set are reliable, and available for a long time series. A well designed policy for oceanographic data (NSF, 1994) could be instrumental in developing well organized programs on ocean data collection, quality check and its storage, making the data reliable for scientific studies.

Apart from being active in the scientific activities, USA,UK, The Netherlands and Germany are producers of many international quality journals (TAPASWI, 1999) which commensurate with the higher level of activities in this subject specialty. Intergovernmental Oceanographic Commission (IOC) under the aegis of United Nations is active in executing multi-institutional and multinational projects. Global Ocean Observing System (GOOS) program is involved in systematic and Scientific Observation of Global Oceans. Joint Global Ocean Flux Studies ( JGOFS ), Sea Level Monitoring and Modeling (SELMAM), Coral Reef Monitoring (GCRMN) are implemented region wise. Its Regional Seas Program designed to provide impetus to regional interests of the oceanic realm. These international programs have boosted the activities in ocean sector in the participating countries.

Socio-economics of knowledge production. Social condition, economic \& political stability of the countries influence the character of knowledge production enterprise. Interplay of various parameters in the self-organizing paradigm provides a character to the production system. The rank order of the coastline of the countries does not follow the productivity profile. Being land locked does not prevent Switzerland to have ocean related interests and make its position to the top layer of the productive countries. In our data set, $85 \%$ productivity goes to G-5 countries (USA,UK, France, Germany and Japan), while $94 \%$ share is accounted by G-7 countries (G-5 + Canada \& Italy). Because the GDP and the productivity are highly unevenly distributed, their logarithms have been used in doing regression analysis. In our data set, the $\mathrm{R}^{2}$ Value for the GDP $(\log )$ vs. productivity is 0.33 , while globally, the empirical relationship between the size of the nations economy - its Gross Domestic Product (GDP) and its productivity volume was found to be moderately high (0.50) (NSF 2000). This may corroborates the fact that only higher GDP may not be the only factor to put the countries on the top of the productivity list; it is an expression of a complex social milieu, impregnated its 
P. G. DASTIDAR: Ocean Science \& Technology

commitments in wisdom, quality of life and other philosophical imperatives. For some countries productivity (articles/\$ billion GDP) goes in excess of what could be expected based on raw economic size (NSF 2000)(Table 2).

Table 2. Socio-economic parameters of the countries

\begin{tabular}{|c|c|c|c|c|c|c|c|c|c|}
\hline Rank & Country & $\begin{array}{c}\text { Coastline } \\
(\mathrm{km})\end{array}$ & $\begin{array}{c}\text { Literacy } \\
(\%)\end{array}$ & $\begin{array}{l}\text { Productivity } \\
\text { (no. of } \\
\text { articles) }\end{array}$ & $\begin{array}{l}\text { World } \\
\text { share } \\
(\%)\end{array}$ & $\begin{array}{l}\text { Log of } \\
\text { produc- } \\
\text { tivity }\end{array}$ & $\begin{array}{c}\text { GDP } \\
\text { Purchasing } \\
\text { power parity } \\
\text { (US \$ } \\
\text { billion) }\end{array}$ & $\begin{array}{l}\text { Log of } \\
\text { GDP } \\
\text { (PPP) }\end{array}$ & $\begin{array}{c}\text { Articles/GDP } \\
\$ \text { billion }\end{array}$ \\
\hline 1 & USA & 19,924 & 97 & 1991 & 42.11 & 3.30 & 8083.0 & 3.91 & 0.25 \\
\hline 2 & UK & 12,429 & 99 & 429 & 9.07 & 2.63 & $1,242.0$ & 3.09 & 0.35 \\
\hline 3 & Germany & 2,389 & "'99" & 383 & 8.10 & 2.58 & 1740.0 & 3.24 & 0.22 \\
\hline 4 & France & 3,427 & 99 & 360 & 7.61 & 2.56 & 1320.0 & 3.12 & 0.27 \\
\hline 5 & Japan & 29,751 & 99 & 263 & 5.56 & 2.42 & $3,080.0$ & 3.49 & 0.09 \\
\hline 6 & Canada & 243,791 & 97 & 228 & 4.82 & 2.36 & 658.0 & 2.82 & 0.35 \\
\hline 7 & Russia & 37,653 & 98 & 202 & 4.27 & 2.31 & 692.0 & 2.84 & 0.29 \\
\hline 8 & Australia & 25,760 & 100 & 195 & 4.12 & 2.29 & 394.9 & 2.6 & 0.49 \\
\hline 9 & Netherlands & 451 & 99 & 147 & 3.11 & 2.17 & 343.9 & 2.54 & 0.43 \\
\hline 10 & Italy & 7,600 & "98 & 125 & 2.64 & 2.10 & $1,240.0$ & 3.09 & 0.10 \\
\hline 11 & New Zealand & 15,134 & 99 & 99 & 2.09 & 1.99 & 63.4 & 1.8 & 1.56 \\
\hline 12 & Spain & 4,964 & 97 & 88 & 1.86 & 1.94 & 642.4 & 2.81 & 0.14 \\
\hline 13 & 'Norway' & "'21,925 & 100 & 82 & 1.73 & 1.91 & 120.5 & 2.08 & 0.68 \\
\hline 14 & Denmark & 7,314 & 100 & 69 & 1.46 & 1.84 & 122.5 & 2.09 & 0.56 \\
\hline 15 & '"Sweden & 3,218 & 99 & 69 & 1.46 & 1.84 & 176.2 & 2.25 & 0.39 \\
\hline 16 & P. R China & 14,500 & 82 & 62 & 1.31 & 1.79 & 4250.0 & 3.63 & 0.01 \\
\hline 17 & 'switzerland & $\begin{array}{c}0 \\
\text { (land locked) }\end{array}$ & 99 & 56 & 1.18 & 1.75 & 172.4 & 2.24 & 0.32 \\
\hline 18 & Greece & 13,676 & 97 & 55 & 1.16 & 1.75 & 137.4 & 2.14 & 0.40 \\
\hline 19 & Taiwan & 1,566 & 86 & 49 & 1.04 & 1.69 & 308.0 & 2.49 & 0.16 \\
\hline 20 & India & 7,000 & 52 & 48 & 1.02 & 1.68 & 1534.0 & 3.19 & 0.03 \\
\hline 21 & Mexico & 9,330 & "'90 & 45 & 0.95 & 1.65 & 694.3 & 2.84 & 0.06 \\
\hline 22 & "Finland" & 1,126 & 100 & 42 & 0.89 & 1.62 & 102.1 & 2 & 0.41 \\
\hline 23 & South Africa & 2,798 & 85 & 42 & 0.89 & 1.61 & 270.0 & 2.43 & 0.16 \\
\hline 24 & Belgium & 66 & 98 & 41 & 0.87 & 1.61 & 236.3 & 2.37 & 0.17 \\
\hline 25 & Brazil & 7,491 & 83 & 41 & 0.87 & 1.61 & $1,040.0$ & 3.02 & 0.04 \\
\hline
\end{tabular}


Thirty-three most productive institutes were selected to produce the network map (Figure 2). NASA (USA) was leading the list followed by Russian Academy of Sciences, NOAA, Woods Hole Institute (USA), University of Washington and University of San Diego.

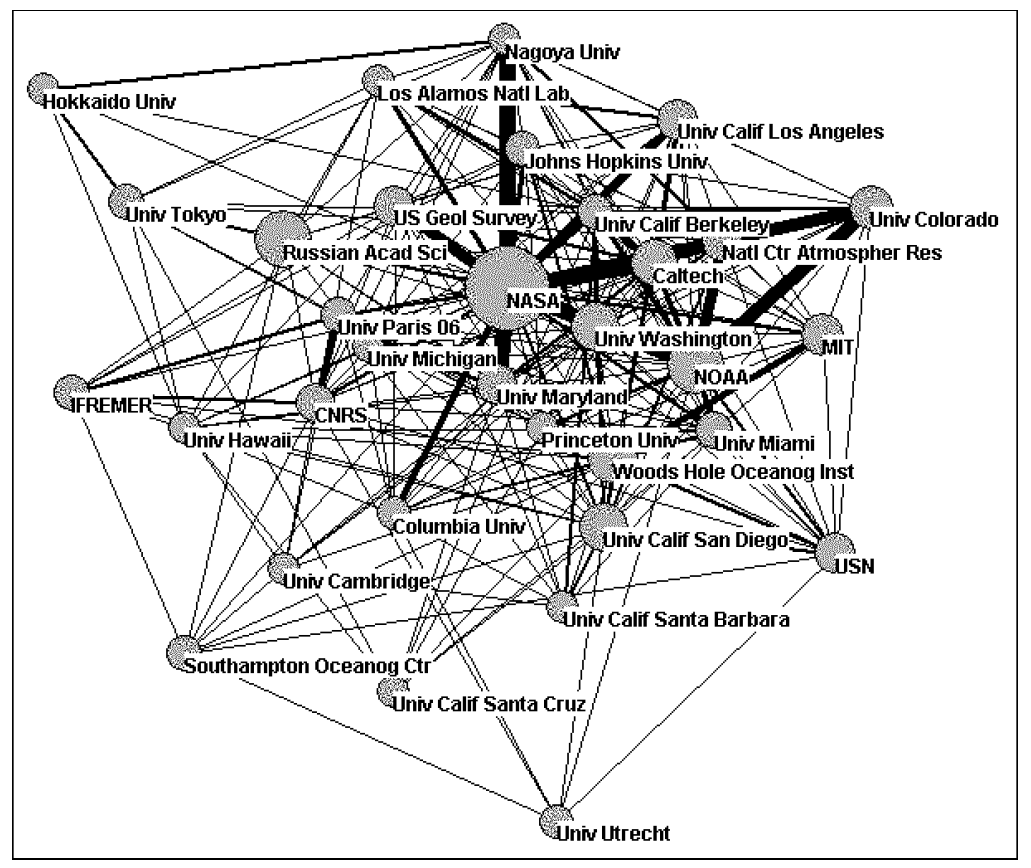

Figure 2. Institutional collaboration map (Co-authorship) 
Table 3. Country affiliations of the most productive institutions

\begin{tabular}{|c|c|c|c|c|c|c|c|}
\hline Rank & Institute & $\begin{array}{l}\text { Productivity } \\
\text { (No. of } \\
\text { articles) }\end{array}$ & $\begin{array}{l}\text { Home } \\
\text { Country }\end{array}$ & $\begin{array}{c}\text { Ran } \\
\mathrm{k}\end{array}$ & Institute & $\begin{array}{l}\text { Productivity } \\
\text { (No. of } \\
\text { articles) }\end{array}$ & $\begin{array}{c}\text { Home } \\
\text { Country }\end{array}$ \\
\hline 1 & NASA & 276 & USA & 18 & IFREMER & 51 & France \\
\hline 2 & Russian Acad Sci & 129 & Russia & 19 & Southampton Oceanog Ctr & 50 & USA \\
\hline 3 & NOAA & 124 & USA & 20 & Univ Paris & 49 & France \\
\hline 4 & Woods Hole Oceanog Inst & 100 & USA & 21 & Univ Calif Berkeley & 49 & USA \\
\hline 5 & Univ Washington & 94 & USA & 22 & Johns Hopkins Univ & 48 & USA \\
\hline 6 & Univ Calif San Diego & 93 & USA & 23 & Columbia Univ & 46 & USA \\
\hline 7 & Caltech & 88 & USA & 24 & Univ Utrecht & 45 & Germany \\
\hline 8 & Univ Colorado & 73 & USA & 25 & Univ Cambridge & 43 & UK \\
\hline 9 & MIT & 71 & USA & 26 & Univ Calif Santa Cruz & 43 & USA \\
\hline 10 & USN & 67 & USA & 27 & Univ Michigan & 43 & USA \\
\hline 11 & Univ Maryland & 67 & USA & 28 & Los Alamos Natl Lab & 43 & USA \\
\hline 12 & US Geol Survey & 64 & USA & 29 & Univ Calif Santa Barbara & 41 & USA \\
\hline 13 & Natl Ctr Atmospher Res & 63 & USA & 30 & Nagoya Univ & 41 & Japan \\
\hline 14 & Univ Calif Los Angeles & 63 & USA & 31 & Princeton Univ & 40 & USA \\
\hline 15 & CNRS & 57 & France & 32 & Hokkaido Univ & 40 & Japan \\
\hline 16 & Univ Miami & 55 & USA & 33 & Univ Hawaii & 40 & Japan \\
\hline 17 & Univ Tokyo & 52 & Japan & & & & \\
\hline
\end{tabular}

\section{Scientist to scientist network}

Co-citation analysis is one of the major quantitative techniques in science studies to map the structure and dynamics of scientific research (BRAAM, 1991). By citing two documents in one article an author establishes a co-citation link. Ocean is a multifaceted subject. Co-citation maps reflect subject similarities and disciplinary structures representing the actual cognitive structure as it is perceived by practicing scientists (LEYDESDORFF, 1987). 50 most cited scientist were considered for making the map. Levitus S, Broecker WS, Press WH, Gill AE, Wyrtki K were some of the scientists leading the list (Figure 3). 


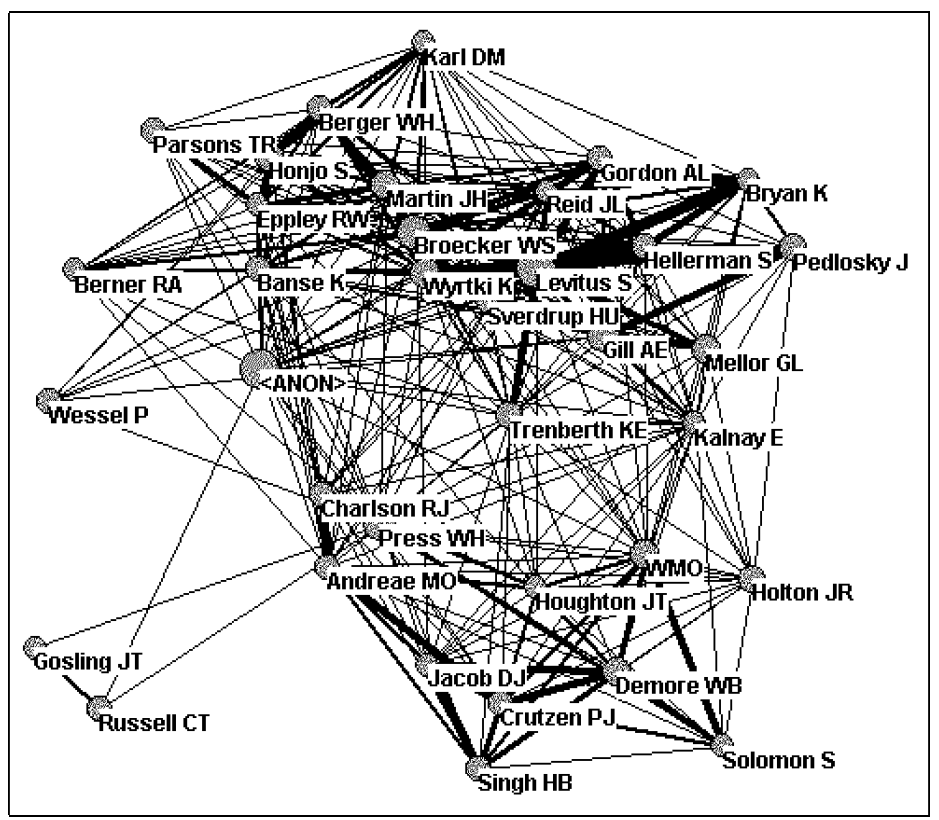

Figure 3. Knowledge cohesion: First author co-citation network

Table 4. Most cited first authors

\begin{tabular}{|c|c|c|c|c|c|}
\hline Rank & $\begin{array}{c}\text { No. of } \\
\text { citations }\end{array}$ & Name & Rank & No. of citations & Name \\
\hline 1 & 148 & Levitus S & 19 & 59 & Crutzen PJ \\
\hline 2 & 147 & Anon & 20 & 59 & Berger WH \\
\hline 3 & 105 & Broecker WS & 21 & 58 & Charlson RJ \\
\hline 4 & 100 & Press WH & 22 & 57 & Hellerman S \\
\hline 5 & 97 & Gill AE & 23 & 56 & Russell CT \\
\hline 6 & 86 & Wyrtki K & 24 & 56 & Parsons TR \\
\hline 7 & 81 & Demore WB & 25 & 55 & Banse K \\
\hline 8 & 75 & WMO & 26 & 54 & Eppley RW \\
\hline 9 & 75 & Martin JH & 27 & 53 & Berner RA \\
\hline 10 & 73 & Honjo S & 28 & 53 & Karl DM \\
\hline 11 & 72 & Mellor GL & 29 & 52 & Sverdrup HU \\
\hline 12 & 70 & Pedlosky J & 30 & 52 & Kalnay E \\
\hline 13 & 69 & Trenberth KE & 31 & 51 & Houghton JT \\
\hline 14 & 64 & Holton JR & 32 & 51 & Solomon S \\
\hline 15 & 62 & Gordon $\mathrm{AL}$ & 33 & 50 & Reid JL \\
\hline 16 & 61 & Wessel P & 34 & 50 & Gosling JT \\
\hline 17 & 60 & Andreae MO & 35 & 50 & Jacob DJ \\
\hline 18 & 59 & Singh HB & 36 & 50 & Bryan K \\
\hline
\end{tabular}




\section{Conclusion}

The present study is a temporal snapshot of the activity dynamics of the knowledge enterprise in Ocean sector. It unravels the structural complexity of the subject. Though the activity dynamics may always be in a changing state, it does show a pattern, particularly in respect to the major players in the field. Study of this kind at a regular time interval will throw much light on the changing pattern vis-à-vis it's causal connections with the socio-economics of the region and its social requirements.

The author expresses his deepest gratitude to Prof. Olle Persson of Inforsk, Umea University, Sweden, for his gracious help in doing this work, without which this work would not have been possible. Thanks to Prof. Robert Hanneman, University of California, Riverside who was always there to help the author to clear doubts in understanding Network Analysis.

\section{References}

Borgatti, S. P., Everett, M. G., Freeman, L. C. (2002), Ucinet for Windows: Software for Social Network Analysis. Harvard: Analytic Technologies.

BONACICH P. (1972), Factoring and weighting approaches to status scores and clique identification, Journal of Mathematical Sociology, 113-120.

BraAm, R. R., MOED, H. F, VAN RAAN, F. J. (1991), Mapping of Science by combined co-citation and word analysis I. Structural Aspects, Journal of the American Society for Information Science, 42 (4) : $233-251$.

CIA, USA, World Fact Book, http://www.odci.gov/cia/publications/factbook/countrylisting.html, accessed on 27th November, 2002.

DAstidar, P. G., BhatTACHARJEe, S. (2001), Ocean research across the countries: A cross-national asessment, International workshop on Emerging trends in Science and Technology indicators: Aspects of collaboration, February 20-25, India.

Hedley, R. A. (2000), Convergence in natural, social and technical system: A critique, Current Science, $79: 592-601$.

Honnyman, R., Introduction to Social Network Analysis, http:/Wizard.ucr.edu/ rhannema, accessed on 2nd April'2001.

Latour, B., Woolgar, S. (1979), Laboratory Life, Beverly Hills, Sage.

LEYDESDORFF, L. (1987), Various methods for the mapping of Science, Scientometrics, 11 : 295-324.

LEYDESDORFF, L. (2001), Scientometrics and the sociology of science, In: The Challenges of Scientometrics, The Development, Measurement and Self Organization of Scientific Communications, Universal Publishers, pp. 15-35.

NAGPAUL, P. S. (2001), Visualizing the cooperation networks of elite institutions in India, Proceedings of the 8th International Conference on Scientometrics \& Informetrics, Vol. 2, Sydney, Australia, July 16-20, pp. 459-468.

NATIONAL SCIENCE BOARD (2000), Science \& Engineering Indicators 2000. Arlington, VA, National Science Foundation.

NATIONAL ScIENCE Foundation (NSF) (1994), Policy for Oceanography Data, NSF 94126. 
Persson, O., BeckmanN, M. (1995), Locating the network of interacting authors in Scientific specialties, Scientometrics, $33: 355-366$.

Persson, O. (2002), BIBEXCEL, a Tool-box for Scientometric Analysis, http;//www.umu.se/inforsk/Bibexcel accessed on 2nd September'2002.

Price, D. J. De Solla (1965), Network of Scientific Papers, Science, 149 No.3683, 510-515.

Small, H. (1973), Co-citation in the scientific literature: A new measure of the relationship between two documents, Journal of the American Society for Information Science, 24 : 265-269.

TAPASWI, M. P., MAHEWARAPPA, B. S. (1999), Ranking serials in oceanography: An analysis based on the Indian contribution and their citation, Scientometrics, $44: 93-127$.

UNCED (1992) Agenda 21: Report of the United Nations Conference on Environment and Development, Chapter 17, 'Protection of the Oceans', http:/www.igc.org/habitat/agenda21/ch-17.html, Accessed on 13th February'2003. 